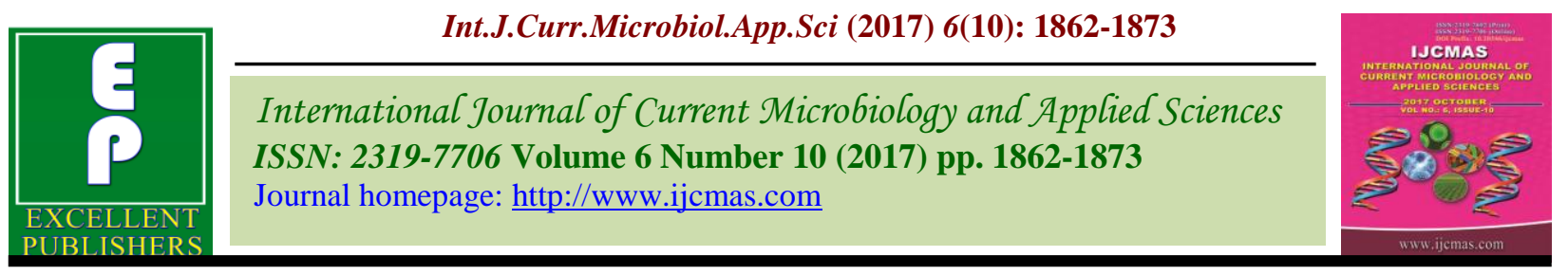

Original Research Article

https://doi.org/10.20546/ijcmas.2017.610.225

\title{
Genetic Variability among High Protease Productive Bacillus Mutants using RAPD-PCR
}

\author{
Effat A.M. Soliman ${ }^{1 *}$, S.E.M Abo-Aba ${ }^{2}$, Nivien A. Abosereh ${ }^{1}$, \\ Nariman A.H. Aly ${ }^{1}$ and Atif D.O. Aljohani ${ }^{2}$ \\ ${ }^{1}$ Microbial Genetic Department, National Research Centre, 33 El-Bohouth St. \\ (Former El-Tahrir St.) Dokki, P.O. 12662, Giza, Egypt \\ ${ }^{2}$ Biological Science Department, Faculty of Science, King Abdulaziz University, \\ Jeddah, Saudi Arabia \\ *Corresponding author
}

\begin{tabular}{|c|c|}
\hline & A B S T R A C T \\
\hline & \multirow{9}{*}{$\begin{array}{l}\text { Proteases enzymes are among the most bio-products required to meet some important } \\
\text { human needs where microbial enzymes participate a big share in the world market for } \\
\text { enzymes. In this study, we aimed to increase the productivity of protease enzyme in } \\
\text { Staphylococcus epidermidis, Bacillus licheniformis, B. thuringiensis, B. subtilis, B. } \\
\text { pumilus, Pseudomonas fluorescens and P. aeruginosa via UV irradiation. We aimed also } \\
\text { to determine the genetic variation among high protease productive mutants using RAPD- } \\
\text { PCR. All strains showed different production levels ranged between } 3.2-58 \mathrm{U} / \mathrm{ml} \text {. The } \\
\text { most efficient productive strains, B. licheniformis and } B \text {. pumilus, were used to examine } \\
\text { the changes that occur in gene expression after exposure to UV as a physical mutagen. Out } \\
\text { of all mutants obtained, two mutants showed higher efficiency in productivity. BLM1-10 } \\
\text { mutant gave nearly twice as much activity produced by } B \text {. licheniformis original strain } \\
\text { while BPM2-10 gave a six and half times higher than activity produced by B. pumilus } \\
\text { original strain. RAPD-PCR data analysis revealed a variability of fragment sizes produced } \\
\text { in wild type strains, B. licheniformis and } B \text {. pumilus, than their UV respective mutants. }\end{array}$} \\
\hline Keywords & \\
\hline & \\
\hline $\begin{array}{l}\text { RAPD analysis, } \\
\text { Genetic variability. }\end{array}$ & \\
\hline Article Info & \\
\hline $\begin{array}{l}\text { Accepted: } \\
17 \text { September } 2017\end{array}$ & \\
\hline & \\
\hline & \\
\hline & \\
\hline
\end{tabular}

\section{Introduction}

Microorganisms are the main source for production of unlimited quantities industrial enzymes. Production methods of microbial protease are relatively simple and welldeveloped. Protease has wide range of industrial applications where the detergent industry for example, is the global market that considered totaling 1.6 billion US dollars (Lakshmi and Prasad, 2015). The genus Bacillus is among the most important organisms for commercial protease production besides many other bacterial Strains (Rahman et al., 1994, Roa et al.,
1998). Proteases is the main enzyme used in detergent industry and all are of Bacillus origin (Roger et al., 2002). Mutation induction and/or selection techniques, together with cloning and protein engineering strategies have been exploited to develop enzyme production (Schallmey et al., 2004). Mutations were resulted by microbial DNA modification either naturally or artificially. Mutations can be arising spontaneous or induced due to any changes in the base sequence of DNA or organism's genome. It can randomly induce DNA lesions in the 
genome (Vijayabaskar et al., 2014). UV irradiation has been used in several studies because of it is characterized by low cost, easy to use and very useful to improve the production of protease enzyme by several bacterial strains (Soliman et al., 2005; Raju and Divakar 2013; Basavaraju et al., 2014). Jamal et al., (2011) obtained three mutants with high lipase production after being treated with UV, where these mutants have given production equivalent to $1.2,2.6$ and 4 folds than obtained by original strain. Soliman et $a l .$, (2005) in their works developed efficient mutants that their protease activities were 2.6, 3.02 and 3.7 folds than those of the original strains. Results obtained by (Basavaraj and Gupta, 2010) indicated that UV radiation and EMS were effective mutagenic agents in increasing enzyme productivity.

Beatriz et al., (2010) obtained mutant from Aspergillus oryzae IPT-301 with highest value of total fructosyl transferase activity after mutated using UV irradiation. Javed et al., (2013) improved the alkaline protease yield by treating the parent $B$. subtilis M-9 strain with UV-irradiations. They obtained BSU-5 mutant strain that showed the hyperactive proteolytic activity of alkaline protease over parent strain and other mutants. Raju and Divakar (2013) enhanced the production of industrially important fibrinolytic protease by subjecting indigenous fibrinolytic protease producing $B$. cereus to strain improvement using ultraviolet irradiation.

Kumar et al., (2009) revealed that the best mutant, Bacillus sp. FME 2 selected from UV irradiation was shown to be the most promising. The yield of glucoamylase generated by the mutant strain was approximately 3.0-fold, which was larger than the yield generated by the wild-type strain. Random amplified polymorphic DNA (RAPD) markers are DNA fragments from
PCR amplification of random segments of genomic DNA with single primer of arbitrary nucleotide (Winfred and Robard 1973; Awad et al., 2011; Sabir et al., 2013). The aim of this study was to examine the effect of UV irradiation on alkaline protease gene expression and induction of overproducing strains. We aimed also to determine the genetic variation among high protease productive mutants using RAPD-PCR. The promising strains in this study may be used in various economic industrial applications and for successive genetic improvement as well.

\section{Materials and Methods}

\section{Bacterial strains and culture conditions}

Seven bacterial strains; Staphylococcus epidermidis, Bacillus licheniformis, $B$. thuringiensis, B. subtilis, B.pumilus, Pseudomonas fluorescens and P. aeruginosa were obtained from Microbial Genetic department, National Research Centre, Giza, Egypt and used in this study. Purified strains cultures were streaked on LB agar slant $(\mathrm{pH}$ 7 ) at $37^{\circ} \mathrm{C}$ for maximum growth rate and stored at $4{ }^{0} \mathrm{C}$.

\section{Media}

Luria- Bertani broth (LB) and (LB agar) media were used to propagate bacterial strains at $37^{\circ} \mathrm{C}$ with vigorous aeration (Davis et al., 1982). For solidification the medium, $1.5 \%$ agar was added. LB agar plus $1 \%$ skim milk was used to detect the production of alkaline protease, i.e., a clear zone of skim milk hydrolysis gave an indication of protease production after incubation at $37^{\circ} \mathrm{C}$ for 40 hours under alkaline conditions (Kunamneni et. al., 2003). Alkaline agar medium was used to subculture bacterial strains (Takami et al., 1989). GYP medium used as production medium of alkaline protease (Roja et al., 2012). 


\section{Determination of Alkaline protease production of tested bacterial strains}

Skim milk used to detect the alkaline protease production according to (Kunammeni et al., 2003). Sterile skim milk was added after autoclaving and cooling to LB agar medium at $37^{\circ} \mathrm{C}$. In situ protease production was demonstrated by the clearing of opaque milk proteins in the area surrounding colonies growing on the surface. Serial dilutions of all tested strains were made up to $10^{-9}$ in sterile water. $0.1 \mathrm{ml}$ of appropriate dilution was added to petri plate on skim milk agar containing $\mathrm{pH} 9.5$ and incubated at $37^{\circ} \mathrm{C}$ for 24h. A clear zone of skim milk hydrolysis around the colonies indicated alkaline protease production by the organism. These colonies were picked and purified by streaking on skim milk agar. The purified proteolytic strains were stored and maintained in LB agar slants ( $\mathrm{pH} 9.5$ ) by sub-culturing at monthly intervals.

\section{Alkaline protease production medium}

GYP medium used as production medium of alkaline protease. The $\mathrm{pH}$ was adjusted to 7.0 - 7.2 followed by media was sterilized by autoclaving at $121^{0} \mathrm{C}$ for 25 minutes. Skim milk sterilized separately and aseptically added to the flask containing LB medium, after cooling. The medium (50 m1 in $250 \mathrm{~m} 1$ conical flask) was inoculated with $1 \mathrm{ml}$ of an overnight culture of tested strains and incubated at $37^{\circ} \mathrm{C}$ in a rotary shaker operated at $150 \mathrm{rpm}$ for 12-hour at time intervals; the turbidity of the culture was determined by measuring the increase in optical density at $450 \mathrm{~nm}$ with a spectrophotometer. After incubation, the production medium was centrifuged at $8000 \mathrm{rpm}$ for $15 \mathrm{~min}$ to separate the cells. The supernatant was collected as it contained the crude enzyme and stored at $4^{0} \mathrm{C}$ until further use.

\section{Alkaline protease assay}

Casein solution of $2 \%(1 \mathrm{ml})$ was incubated with $0.1 \mathrm{ml}$ of enzyme solution and $0.9 \mathrm{ml}$ of sodium phosphate buffer $(\mathrm{pH}$ 7) for 10 minutes at $37^{\circ} \mathrm{C}$. The reaction was stopped using $10 \%$ trichloro acetic acid (TCA) solution. After 20 minutes, the mixture was centrifuged $8000 \mathrm{rpm}$ for 5 minutes. The color intensity of supernatant was read at 280 $\mathrm{nm}$. The enzyme activity was calculated from standard curve of tyrosine already prepared. One unit enzyme activity was taken as the amount of enzyme producing $1 \mu \mathrm{g}$ of tyrosine under standard assay conditions and expressed as $\mathrm{U} / \mathrm{ml}$ enzyme (Boominadhan et al., 2009).

\section{Mutagenesis by UV treatment}

UV mutagenesis was carried out according to (Justin et al., (2001) using different exposure times and radiation intensities i.e., distances from irradiation source. Overnight loopful culture of the most efficient productive strains was transferred from slant into $50 \mathrm{ml}$ LB broth and incubated at $37^{\circ} \mathrm{C}$ for 12 -hour at $140 \mathrm{rpm}$ on an incubatory shaker, at $\mathrm{pH} 9.5$. After that, $10 \mathrm{ml}$ of the inoculated broth was centrifuged at $4000 \mathrm{rpm}$ for $10 \mathrm{~min}$ at $4^{0} \mathrm{C}$ and the supernatant was decanted. The cell pellets were washed thoroughly with sterile saline $(0.9 \% \mathrm{NaCl})$ followed by sterile distilled water. Finally, the cell mass was suspended in sterile saline and used as a source of cell suspension for irradiation and subsequent experiments. Various serial dilutions of cell suspension were prepared and the dilution $10^{-}$ $7 / \mathrm{ml}$ was distributed into different round sterilized disposable petri dishes $(2 \mathrm{ml}$ in each petri plate) in dark and irradiated for 5 to 120 min in UV chamber keeping the distance of UV source fixed at 10 and $15 \mathrm{~cm}$. $15-\mathrm{W}$ germicidal lamp (254 $\mathrm{nm}$ ) was used. We are protected by hanging the lamp behind a black curtain. 
Dishes are placed on a tray and the lids are removed immediately before being placed behind the curtain. It is imperative that lids are removed to permit UV exposure; it is also critical that the dishes (not the lids) are labeled before irradiation to keep track of strains and treatments. The treated samples were transferred into sterile test tubes covered with a black paper and kept in the refrigerator overnight to avoid photo reactivation. $0.5 \mathrm{ml}$ of suitable dilution of each strain was spread on skim milk agar media plates at $\mathrm{pH} 9.5$ and incubated for 24 -hour at $37^{\circ} \mathrm{C}$. Colonies developed after incubation were counted and the percentage of survival was calculated over the control (plate was kept aside in dark without UV treatment).

\section{Genomic DNA extraction}

Genomic DNA was extracted from the most efficient productive strains and their best resulting mutants using Easy Quick DNA extraction kit (Genomix) following the manufacturer's instructions.

\section{Random amplified polymorphic DNA (RAPD-PCR)}

PCR reactions carried out using five arbitrary 10-mer primers (Bioneer; South Korea). PCR reactions were conducted using $2 \mathrm{x}$ superhot PCR Master Mix (Qiagen; Germany) with 10 Pmol of each five-different arbitrary 10-mer primers. The codes and sequences of these primers listed in Table 4 . The $25 \mu \mathrm{l}$ reaction mixture was (10 Pmol of each primer, 30-50 ng of DNA template and $12.5 \mu \mathrm{l}$ of $2 \mathrm{x}$ superhot PCR Master Mix). PCR protocol was initial denaturation, $94^{\circ} \mathrm{C}$ for $5 \mathrm{~min}$ and 40 cycles of subsequent denaturation, $94^{\circ} \mathrm{C}$ for $30 \mathrm{~s}$; annealing temperature, $38^{\circ} \mathrm{C}$ for $30 \mathrm{~s}$; extension temperature, $72^{\circ} \mathrm{C}$ for $2 \mathrm{~min}$ and final extension, $72^{\circ} \mathrm{C}$ for $10 \mathrm{~min}$. PCR products were analyzed on $1 \%$ agarose gel electrophoresis with 100bp DNA ladder standard (Jena Bioscience, Germany) for 30 min using Tris-borate- EDTA Buffer, and visualized by ultraviolet illumination after staining with $0.5 \mu \mathrm{g} / \mathrm{ml}$ ethidium bromide. A pair of RAPD for each five primers applied to amplify DNA isolated from tested strains and their mutants under study. Their sequences and total scored fragments produced by each primer among studied strains and their mutants shown in Tables 4 and 5.

\section{Data Analysis}

RAPD data was analyzed using Statistical Package for Social Science (SPSS), version 10 (SPSS Inc, Chicago, Illinois, USA) software. A genetic similarity (GS) was computed based on Jaccard coefficient of similarity. Each RAPD fragment was treated as a unique character and was scored as one (present) or zero (absent). The 1/0 matrix was prepared for all fragments and used to generate Jaccard coefficient of similarity and recorded accordingly.

\section{Results and Discussion}

\section{Determination of alkaline protease} activityof tested bacterial strains

Alkaline protease assay was estimated following the procedure of (Boominadhan et al., 2009). Results were illustrated in Table 1 and (Figs. 1 and 2) which proved that $B$. licheniformis was the most efficient in enzyme production followed by $B$. pumilus. In contrast, the rest showed a broad range of productivity i.e., 3.2 to $10 \mathrm{U} / \mathrm{ml}$.

\section{UV irradiation and selection of hyper- proteolytic mutants}

The mutation and screening of commercially viable microorganisms are important for the successful development of various strains required in the fermentation industry. 
Therefore, the parent strains $B$. licheniformis and $B$. pumilus were treated with UV irradiation to improve their productivities. Results in (Table 2) and (Figs. 1 and 2) revealed that the survival rate decreased gradually with the increase of exposure time. It also decreased gradually as increasing the radiation intensities, i.e., distances and became $0 \%$ after exposure of $120 \mathrm{~min}$ at both distance of 10 and $15 \mathrm{~cm}$. Mutants after UV irradiation developed colonies were inoculated into LB plus 1\% skim milk agar medium under alkaline conditions and incubated at $40^{\circ} \mathrm{C}$ for $24 \mathrm{~h}$. Depending upon the zone of clearance mutants with high activity compared to parental strains selected. The enzyme activity of superior alkaline protease producing mutants was assayed according to the method of (Roja et al., 2012) using GYP medium. One unit of the enzyme activity defined as amount of enzyme producing $1 \mu \mathrm{g}$ of tyrosine under standard assay conditions and expressed as $\mathrm{U} / \mathrm{ml}$ of enzyme.

Eight hyper-proteolytic positive mutants primarily selected based on zone of clearance on skim milk agar plates and assayed for their enzyme activity as shown in Table 3. Results in Table 3 showed that the values of alkaline protease production of mutant strains ranged from 79 for PFM1-15 mutant to 111 for the corresponding BPM2-10. Data also revealed that mutant strains, BLM1-10 and BPM2-10 gave the highest enzyme production. BPM210 was more than six times productivity of $B$. pumilus original strain while BLM1-10 was nearly twice productivity of $B$. licheniformis. Soliman et al., (2005); Jamal et al., (2011) and Javed et al., (2013) were done similar studies and obtained results that agreement with our obtained in this study. Jamal et al., (2011) reported that the survival percentages were decreased by increasing both of time of exposure and radiation intensities, i.e., distances. They obtained three mutants with high lipase production after being treated with UV, where these mutants have given production equivalent to $1.2,2.6$ and 4 folds than obtained by original strain. On another hand, Soliman et al., (2005) obtained three most efficient mutants that their protease activities were 2.6, 3.02 and 3.7 folds than those of the original strains. Basavaraj and Gupta (2010) demonstrate the effectiveness of ultraviolet (UV) radiation when they improved production of bacterial cellulose. Beatriz et al., (2010) obtained mutant from Aspergillus oryzae IPT-301 with highest valuetotal of $\beta$-fructofuranosidase activity after mutated using UV irradiation. Javed et al., (2013) improved the alkaline protease yield by treating the parent Bacillus subtilis M-9 strain with UV-irradiations. They obtained BSU-5 mutant strain that showed the hyperactive proteolytic activity of alkaline protease over parent strain and other mutants. Raju and Divakar (2013) enhanced the production of industrially important fibrinolytic protease by subjecting indigenous fibrinolytic protease producing Bacillus cereus by random mutagenesis using ultraviolet (UV) irradiation and ethidium bromide treatment. They proved that ethidium bromide was the best for optimum production of fibrinolytic protease. EB-15 mutant was found to produce 2-4-fold more enzyme. Kumar et al., (2009) revealed that the best mutant, Bacillus sp. FME 2, selected from UV irradiation and EtBr, was shown to be the most promising and the yield of glucoamylase generated by the mutant strain was approximately 3.0 -fold which was larger than the yield generated by the wild-type strain.

In addition to the above listed, the same results obtained in this study agreed with other results obtained by (Basavaraju et al., 2014; Ghazi et al., 2014; Arotupin et al., 2014).Mutant strains showed different responses to UV radiation for alkaline protease production. These variations are 
more probably due to the differences induced in their genetic background. Therefore, results obtained revealed variation in gene expression, i.e., enzyme activity as reported by (Justin et al., 2001). Variations may be also due to some factors, e.g., damage or mutation occurs in gene (s), differences in their ability of repairing their DNA, the repair enzymes themselves are damaged and the repair mechanism is not universal, so replication cannot take place again (Ben, 2003). Uehara et al., (1974) proposed the presence of regulator genes responsible to produce alkaline protease. In addition, mutations led to the overproduction of proteases may also include those genes that could modify the productivity rather than the structure genes themselves. Nagami and Tanaka (1986) proved that mutation of genes controlling cell membrane composition led to the hyperactive production of proteases. They also pointed to the effect of mutations on regulatory genes that are associated with the structural genes. However, the application of UV irradiation, whatever the mutation(s) include either modifying or structural genes, led to the isolation of hyperactive enzyme producing cultures (Qadeer et al., 1980). Finally, these results suggest that induction of mutation by UV irradiation was more effective in getting super strains in productivity.

Table.1 Alkaline protease activity of tested bacterial strains at $\mathrm{pH} 9$

\begin{tabular}{|l|c|}
\hline Strain & Enzyme activity U/ml \\
\hline Bacillus licheniformis & 58.00 \\
\hline Bacillus pumilus & 17.00 \\
\hline Pseudomonas fluorescens & 10.90 \\
\hline Bacillus thuringiensis & 7.00 \\
\hline Pseudomonas aeruginosa & 3.50 \\
\hline Staphylococcus epidermidis & 3.60 \\
\hline Bacillus subtilis & 3.20 \\
\hline
\end{tabular}

Table.2 Survival \% after UV exposure using different periods at distance of 10 and $15 \mathrm{~cm}$

\begin{tabular}{|c|c|c|c|c|}
\hline \multirow[t]{2}{*}{ Exposure time inmin. } & \multicolumn{2}{|c|}{ No. of cells after irradiation } & \multicolumn{2}{|l|}{ Survival (\%) } \\
\hline & B. licheniformis & B. pumilus & B. licheniformis & B. pumilus \\
\hline \multicolumn{5}{|c|}{ at distance of $10 \mathrm{~cm}$} \\
\hline 0 & 820 & 975 & 100 & 100 \\
\hline 15 & 605 & 543 & 74 & 56 \\
\hline 30 & 490 & 312 & 60 & 32 \\
\hline 45 & 103 & 65 & 13 & 7 \\
\hline 60 & 45 & 21 & 5 & 2 \\
\hline 90 & 11 & 8 & 1 & 1 \\
\hline 120 & 2 & 1 & 0 & 0 \\
\hline \multicolumn{5}{|c|}{ at distance of $15 \mathrm{~cm}$} \\
\hline 0 & 1204 & 1104 & 100 & 100 \\
\hline 15 & 599 & 642 & 50 & 58 \\
\hline 30 & 287 & 301 & 24 & 27 \\
\hline 45 & 67 & 69 & 6 & 6 \\
\hline 60 & 23 & 21 & 2 & 2 \\
\hline 90 & 4 & 3 & 0 & 0 \\
\hline 120 & 1 & 1 & 0 & 0 \\
\hline
\end{tabular}


Table.3 Enzyme activities of mutant strains

\begin{tabular}{|l|l|l|l|}
\hline Mutant strains & Enzyme Activity & Mutant strains & Enzyme Activity \\
\hline BLM1-10 & 104 & PFM3-10 & 93 \\
\hline BLM2-10 & 87 & PFM4-15 & 100 \\
\hline BLM3-15 & 99 & BPM1-15 & 87 \\
\hline PFM1-15 & 79 & BPM2-10 & 111 \\
\hline
\end{tabular}

Table.4 Five primers used, their nucleotide sequences and total number of resulting bands

\begin{tabular}{|l|l|c|c|c|c|c|}
\hline \multirow{2}{*}{$\begin{array}{l}\text { RAPD } \\
\text { Primers }\end{array}$} & \multirow{2}{*}{ Type of sequences } & \multicolumn{6}{|c|}{$\begin{array}{l}\text { Number of bands produced by wild type } \\
\text { strains and their mutants }\end{array}$} & $\begin{array}{l}\text { Total no. } \\
\text { of bands }\end{array}$ \\
\cline { 3 - 6 } & & Sew & Sem & Btw & Btm & \\
\hline UBC 55 & 5'-TCCCTCGTGC-3' & 15 & 14 & 5 & 4 & 38 \\
\hline UBC 37 & 5'-GGGCACGCGA-3' & 14 & 13 & 17 & 16 & 60 \\
\hline UBC 88 & 5'-CGGGGGATGG-3' & 15 & 6 & 18 & 18 & 57 \\
\hline UBC96 & 5'-GGCGGCATGG-3' & 13 & 16 & 14 & 10 & 53 \\
\hline UBC 97 & 5'-ATCTGCGAGC-3' & 21 & 11 & 14 & 14 & 60 \\
\hline Total & & 78 & 60 & 68 & 62 & 268 \\
\hline
\end{tabular}

Table.5 Monomorphic and polymorphic bands produced by five primers

\begin{tabular}{|l|l|l|l|l|l|l|}
\hline \multirow{2}{*}{$\begin{array}{l}\text { Primer } \\
\text { name }\end{array}$} & \multicolumn{3}{|c|}{ Sew and Sem } & \multicolumn{3}{c|}{ Btw and Btm } \\
\cline { 2 - 7 } & $*$ & $* *$ & $* * *$ & $*$ & $* *$ & 1 \\
\hline UBC 55 & 29 & 3 & 13 & 9 & 11 & 4 \\
\hline UBC 37 & 27 & 14 & 13 & 33 & 18 & 7 \\
\hline UBC 88 & 21 & 15 & 6 & 36 & 18 \\
\hline UBC96 & 29 & 11 & 9 & 24 & 7 & 10 \\
\hline UBC 97 & 32 & 14 & 9 & 28 & 0 & 14 \\
\hline Total & 138 & 57 & 50 & 130 & 37 & 53 \\
\hline
\end{tabular}

(*) Amplified, (**) Polymorphic and (***) Monomorphic bands

Fig.1 Zone of clearance resulting from $B$. licheniformis and its resulting mutants

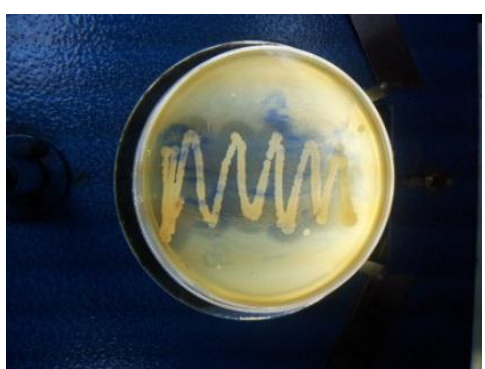

B. licheniformis

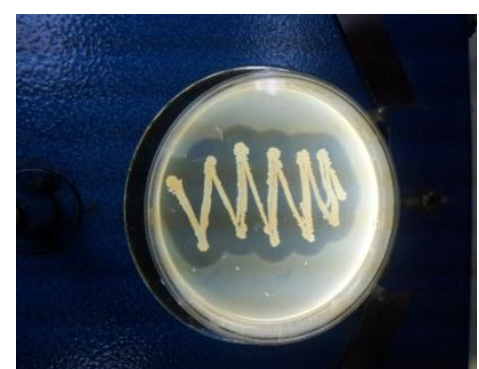

BLM1-10

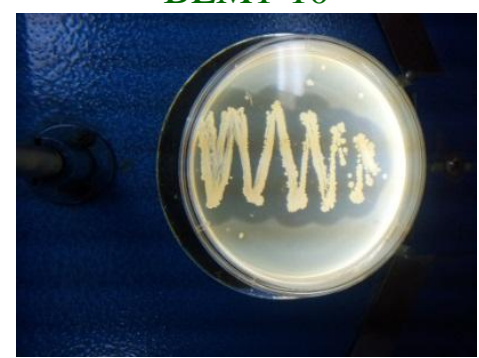

BLM2-10

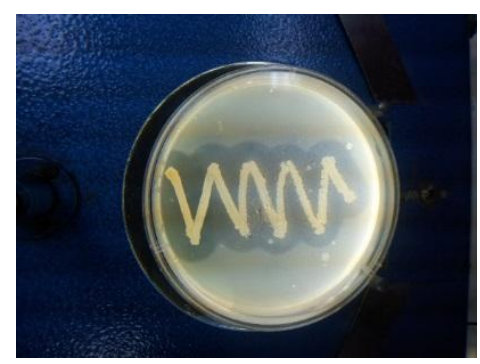

BLM3-15 
Fig.2 Zone of clearance resulting from B. pumilus and its resulting mutants

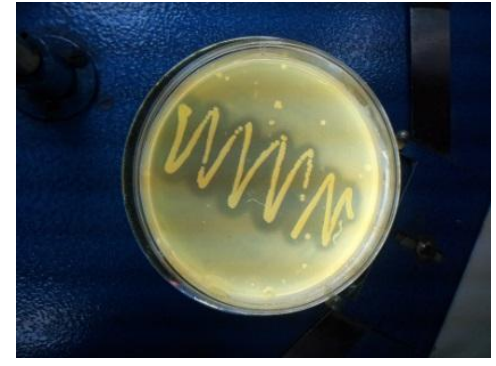

B. pumilus

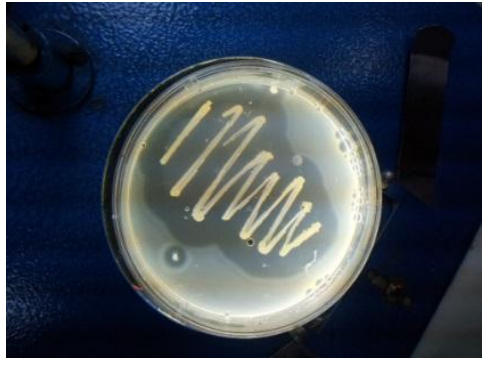

BPM2-15

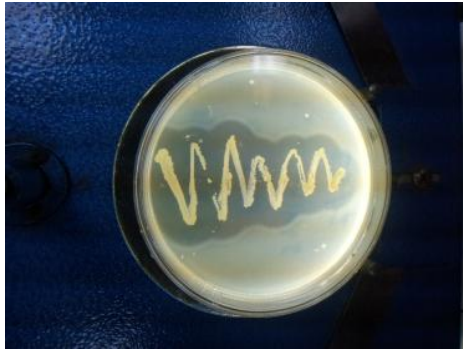

BPM1-10

Fig.3 Random Amplified Polymorphic DNA pattern of Isolated DNA from (B. licheniformis and B. pumilus) and their resulting mutants by using five Different RAPD primers
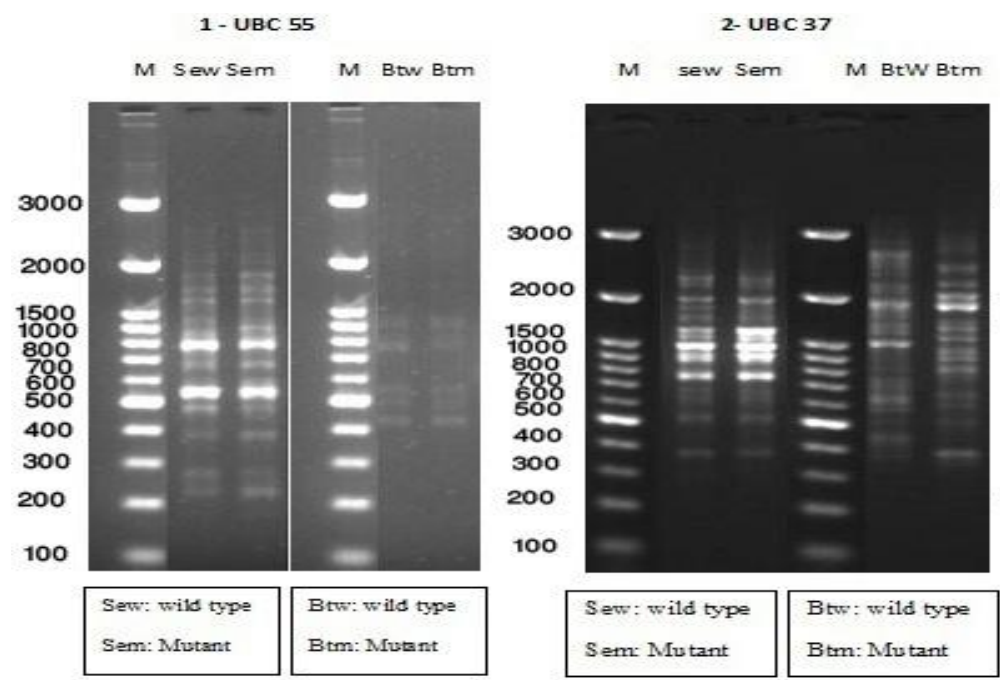
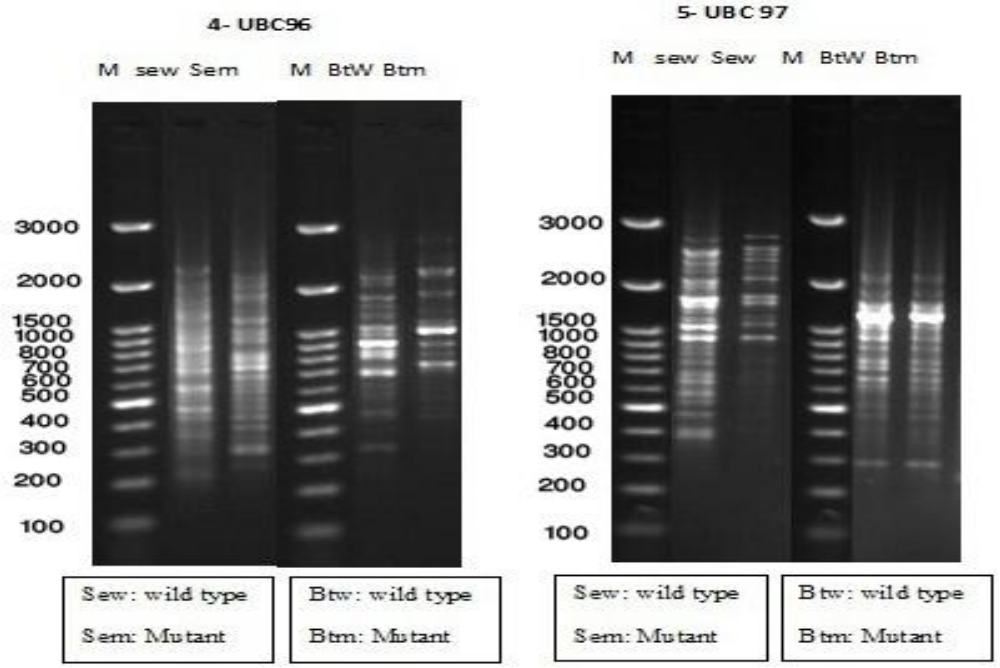

Sew $=$ B. licheniformis (Wild type with enzyme activity $58.0 \mathrm{U} / \mathrm{ml}$ )

Sem $=$ BLM1-10 $($ B. licheniformis mutant with enzyme activity $104 \mathrm{U} / \mathrm{ml})$

$\mathrm{Btw}=B$. pumilus (Wild Type with enzyme activity $17.0 \mathrm{U} / \mathrm{ml}$ )

$\mathrm{Btm}=\mathrm{BPM} 2-10$ (B. pumilus mutant with enzyme activity $111 \mathrm{U} / \mathrm{ml})$ 


\section{Molecular characterization}

Genomic DNA extracted from the most efficient wild type productive strains, $B$. licheniformis (Sew) and B. pumilus (Btw). DNA was also extracted from their best resulting mutants, (Sem) and (Btm), respectively. B. licheniformis wild type strain showed productivity of $58.0 \mathrm{U} / \mathrm{ml}$ while its BLM1-10 mutant (Sem) gave104 U/ml. On the other hand, B. pumilus wild type strain showed productivity of $17.0 \mathrm{U} / \mathrm{ml}$ while its BPM2-10 mutant (Btm) gave $111 \mathrm{U} / \mathrm{ml}$. RAPD was carried out with five primers generated different patterns with all used primers. The five RAPD primers amplified both wild type strains (Sew, Btw) and their best resulting mutants (Sem and Btm) with several fragments at different molecular weight sizes as indicated in Figure 3. RAPD analysis performed with good quality for the two physically treated, the two wild type strains and their mutant strains with five RAPD primers. The number of bands produced by wild type strains and their mutants indicated in Table 4 for their ability to differentiate wild type and mutated strain variation. The Monomorphic and polymorphic bands produced by five used primers presented in Table 5.

RAPD data represented that the visualization of bands in case of $B$. licheniformis (Sew) wild type strain and its mutant (Sem) with UBC 55 primer shown similarity in generated bands at different molecular weight sizes but one band appeared at ca. 2800 base pair in (Sem) mutant not found at its wild type (Sew). The same results also generated by UBC 73 primer but high intensity bands produced from 1500 to 700 base pairs with (Sew). In the case of UBC 88 primer the wild type (Sew) produced 15 fragments but only 6 fragments in their mutant (Sem), 9 fragments absent from mutant strain, four fragments absent at ca 3000 to 2500 base pairs, two fragments absent at ca. 1800 and 1700 base pairs and three fragments absent from 700 to 500 base pair. In the case of UBC 96 primer low intensity of fragments visualized in mutant (Sem) than their wild type (Sew) strain and incomplete or partial fragments produced from 300 to 200 base pairs. In the case of UBC 97 primer 21 band produced by this primer in wild type (Sew) strain and only 11 bands generated in its (Sem)mutant, 10 bands absent in mutant (Sem) strain from 1000 to 400 base pair. On the other hand, in case of B. pumilus (Btw) wild type strain, the random amplified polymorphic DNA's of the wild type strain (Btw) and its mutant (Btm) carried out with the same RAPD primers. By UBC 55 primer, the visualized similarity in generated bands at different molecular weight sizes of both wild type and mutant strain, 17 fragments produced in (Btw) wild type but 16 fragments in their mutant (Btm), one fragments absent at ca 300 base pair in (Btm) mutant strain, and heavier fragments recorded at about ca 2100 to 1800 base pair.

In the case of UBC 88 primer the visualized similarity in generated bands at different molecular weight sizes. In the case of UBC 96 primer 14 fragments produced in (Btw) wild type strain and only 10 fragments produced at (Btm) mutant strain 4 fragments absent in (Btm) mutant than in wild type (Btw) at ca. $2100,600,500$ and 300 base pair respectively, also heavier fragment produced in (Btm) mutant at ca. 2400 base pair noted, and high intensity of bands in (Btw) wild type noted at ca 1500 to 700 base pair not found in (Btm) mutant strain. In the case of UBC 97 primer shown similarity in generated bands at different molecular weight sizes of both (Btw) wild type and (Btm) mutant strain, but high intensity of bands visualized at ca. 1800 to 500base pairs in (Btw) strain. The mutants resulting of both wild type strains yielded different fragments than their wild type strains with some variation of fragment size in 
some of used random primers. These data represent the variation happened in genome of mutant strains by UV mutagenesis.

RAPD PCR applied to test the effect of UV irradiation on the $B$. licheniformis and $B$. pumilus strains. Differences in RAPD-PCR patterns between wild type and their UV irradiated mutants revealed that RAPD PCR detects differences along the entire bacterial genome. Thus, this system is helpful in characterize the variation of bacterial strains and can find changes along the genome after UV irradiation of bacterial isolates. Basavaraju et al., (2014), indicates the same results. Consequently, the use of RAPD-PCR can detect any differences between the genome of UV irradiated and non-irradiated bacterial isolates. Genetic variation among different strains can be documented by using different molecular markers (Winfred and Robard, 1973; Awad et al., 2011; Sabir et al., 2013; Abdalnabi and Essam, 2014). Son et al., (2012) demonstrated that the $P$. fluorescens $\triangle$ tliA $\triangle p r t A$ deletion mutant enhances production and detection of recombinant proteins in extracellular media. The genetic variability between the closely related organisms studied by using this RAPD technique (Devi et al., 2014).

\section{References}

Abdalnabi, J. A., and Essam, Z. 2014. Random amplification polymorphic DNA, a good epidemiologic screening method for nosocomial isolates of Pseudomonas aeruginosa. European Journal of Biology and Medical Science Research, 2(1): 37-44,

Arotupin, D. J., Akinyele, B. J. and Olaniyi, O. O. 2014. Influence of UV Mutagenesis on $\beta$-Mannanase Production Potential of Aspergillus glaucaus and Rhizopus japonicas. BMRJ, 5(6): 466-473.
Awad, N. S., Sabit, H. H., Abo-Aba, S. E. M. and Bayoumi R. A. 2011. Isolation, characterization, and fingerprinting of some chlorpyrifos-degrading bacterial strains isolated from Egyptian pesticides-polluted soils. Afr. J. Microbiol. Res., 5(18): 2855-2862.

Basavaraj, S. H., and Gupta, S. G. (2010).Strain improvement of Gluconacetobacter xylinus NCIM 2526 for bacterial cellulose production. African Journal of Biotechnology, 9(32): 5170-5172.

Basavaraju, S., Kathera, C. and Jasti, P.K. 2014. Induction of alkaline protease production by Bacillus mutants through UV irradiation. Int. J. Pharm. Sci. Rev. Res., 26(1): 78-83.

Beatriz, G. M., Castillo, B. G., Fernández, R. C., da Silva, E. S., Maiorano, A. E. and Rodrigues, M. F. de Andrade, 2010. Mutagenesis of Aspergillus oryzae ipt301 to improve the production of $\beta$ fructofuranosidase. Braz. J. Microbiol., 41: 186-195.

Ben, F.K., 2003. Microbial repair mechanisms after UV treatment. Technical Background Article, Berson UV- Techniek, 1: 1-4.

Boominadhan, U., Rajakumar, R., Sivakumaar, P. K. V. and Joe, M. M. (2009). Optimization of protease enzyme production using Bacillus $\mathrm{Sp}$. Isolated from different wastes. Bot. Res Int., 2(2): 83-87.

Davis, R. W., Botstein, D. and Roth, J. R. 1982. A manual for genetic engineering: Advanced bacterial genetics, Cold Spring Harber La., Cold Spring Harber, New York.

Devi, M., Nithyananthi, M.J.T., Nithya, R., Romauld, S. I., Nithya, R. and Jayashree, R. 2014. Genetic variability among protease producing microorganism using RAPD technique. Int. J. ChemTech. Res., 6 (9): 4312 
4317.

Ghazi, S., Sepahy, A. A., Azin, M., Khaje, K. and Khavarinejad, R. 2014. UV mutagenesis for the overproduction of xylanase from Bacillus mojavensis PTCC 1723 and optimization of the production condition. Iran. J. Basic. Med. Sci., 17(11): 844-853.

Hungund, B.S., Gupta, S.G. 2010. Improved production of bacterial cellulose from Gluconacetobacter persimmonis $\mathrm{GH}-2$. J. Microb. Biochem. Technol., 2:127133.

Jamal, S. M. S., Effat A. M. Soliman and Mutawakil, M. H. Z. 2011. Genetic improvement of Bacillus licheniformis for lipase production through UV irradiation, J. Biotech. Res., 11:75-81.

Javed, S., Meraj, M., Bukhari, S.A., Irfan, R., Mahmood, S. 2013. Hyper-production of alkaline protease by mutagenic treatment of Bacillus subtilis M-9 using agro industrial wastes in submerged fermentation. J. Microb. Biochem. Technol., 5: 074-080.

Justin, C., Khodursky, A.; Peter, B.; Brown, P.O. and Hanawalt, P.C. (2001). Comparative gene expression profiles following UV exposure in wild type and SOS-deficient Escherichia coli. Genetics, 158:41-64.

Kumar, G.S., Chandra, M. R. G. S., Sujana, Y. N., Reddy, B. R. and Choi, Y. L. 2009. Enhanced production and partial purification of glucoamylase from mutated Bacillus sp. FME. J. Korean Soc. App. Biol. Chem., 52(5): 412-418

Kunamneni, A., Poluri, E. and Davuluri, S. P. 2003. Purification and partial characterization of thermostable serine alkaline protease from a newly isolated Bacillus subtilis PE-11, AAPS Pharm. Sci. Tech., 4 (4):440-480.

Lakshmi, G., and Prasad, N.N. 2015. Purification and characterization of alkaline protease from a mutant Bacillus licheniformis B18. Advan. Biol. Res., 9 (1): 15-23.

Nagami, Y., and Tanaka, T. 1986. Molecular cloning and nucleotide sequence of a DNA fragment from Bacillus natto that enhances production of Extracellular proteases and levansucrase in Bacillus subtilis. J. Bacteriol., 166(1): 20 - 28.

Qadeer, M.A., Anjum, J.I. and Akhtar, R. 1980. Biosynthesis enzymes by solid substrate fermentation. Part II: Production of alpha-amylase by Bacillus subtilis Pak. J. Sci. Indus. Res., 23(1): 25-29.

Rahman, R.N.Z.A., Razak, C.N., Ampon, K., Basri, M., Yunus, W.M.Z. and Salleh, A.B. 1994. Purification and characterization of a heat-stable alkaline protease from Bacillus stearothermophilus F1. Appl. Microbiol. Biotechnol, 40: 822-827.

Raju, E. V. N. and Divakar, G. 2013. Bacillus Cereus GD 55 strain improvement by physical and chemical mutagenesis for enhanced production of fibrinolytic protease. IJPSR, 4(5):81-93.

Rao, M.B., Tanksale, A.M., Ghatge, M.S. and Deshpande, V.V. 1998. Molecular and biotechnological aspects of microbial proteases. Microbiol. Mol. Biol. Rev., 62: 597-635.

Roger, B., Marc, H., Niall, L. and Paul, D.V. 2002. Application and systematic of Bacillus and relatives. Blakwell Publishing Company, U.S.206-219.

Roja, M. R., and Prasad, N.N. 2012. Strain improvement of Aspergillus flavus for enhanced production of alkaline protease enzyme. IJSID, 2 (1):113-120.

Sabir, J. S., Abo-Aba, S.E.M., Said, M. M., Hussein, R. M., Al-Saud, N. and Mutwakil, M. 2013. Isolation, identification, and RAPD-PCR analysis of new isolated Bacillus thuringiensis. Life Sci. J., 10 (2):1352- 1361. 
Schallmey, M., Singh, A., and Ward, O.P. (2004). Developments in the use of Bacillus species for industrial production. Can. J. Microbiol., 50(1): 17.

Soliman, E.A.M., Hegazy, W. K. and Moharam, M. E. 2005. Induction of overproducing alkaline protease Bacillus mutants through UV irradiation. Arab J. Biotech. 8, (1): 4960.

Son, M., Moon, Y., Oh, M. J., Han, S. B., Park, K.H., Kim, J. and Ahn, J. H. 2012. Lipase and protease double-deletion mutant of Pseudomonas fluorescens suitable for extracellular protein production. Appl. Environ. Microbiol, 78 (23): 8454- 8462.

Takami, H., Akiba, T. and Horikoshi, K.
1989. Appl. Microbiol. Biotechnol. 30: 120-124.

Uehara, H.K., Yonder, Y., Yamane K. and Maruo, B. 1974. Regulation of neutral protease productivity in Bacillus subtilis Transformation of high protease productivity. J. Bacteriol. 92 - 92 .

Vijayabaskar, P., Revathi, M., Shankar, T., Sivakumar, T. 2014. Effect of UV irradiation and Ethyl Methyl Sulphate on Carboxy Methyl Cellulase production by Bacillus pumilus. I.J.M.C.A., 4(1): 35-40.

Winifred, F.D., and Robards, A.W. 1973. Ultrastructural study of poly- $\beta$ hydroxybutyrate granules from Bacillus cereus. J. Bacteriol., 114(3):1271-1280.

\section{How to cite this article:}

Effat A.M. Soliman, S.E.M Abo-Aba, Nivien A. Abosereh, Nariman A.H. Aly and Atif D.O. Aljohani. 2017. Genetic Variability among High Protease Productive Bacillus Mutants using RAPD-PCR. Int.J.Curr.Microbiol.App.Sci. 6(10): 1862-1873.

doi: https://doi.org/10.20546/ijcmas.2017.610.225 